Clinical trials are particularly taxing in patients with the carcinoid syndrome. Studies of the impact of treatment on mortality are difficult because survival may be prolonged and the range is wide. The rarity of the disease also means that such studies cannot be done in a single centre. Comparative studies that measure the quality of life are also difficult because patients vary so much in both the severity and their tolerance of symptoms. Studies at different times in the same patient may, however, be valuable.

The best policy at the moment seems to be to control mild symptoms if necessary with simple blocking drugs and then to resort to somatostatin when these are no longer enough. Embolisation of the hepatic artery or chemotherapy should be considered when somatostatin is no longer effective.

H J F HODGSON

Reader in Gastroenterology,

Royai Postgraduate Medical School,

London W12 0HS
2 Keane TS, Rider WS, Harwood HR. Whole abdominal irradiation in the management of metastatic gastrointestinal carcinoid tumour. Int f Radiat Oncol Biol Phys 1981;7:1519-21.

Kimming BN, Georgi P, Adolph JMG, Zum Winkel K. Carcinoid tumours, CT and 131 I-me

Galland RB, Blumgart LH. Surgical management of carcinoid syndrome. Br 7 Hosp Med 1986;35: 166-70.

5 Stephen JL, Graeme-Smith DG. Treatment of the carcinoid syndrome by local removal of hepatic metastases. Proceedings of the Royal Society of Medicine 1972;65:444-5.

6 Kvols LK. Metastatic carcinoid tumours and the carcinoid syndrome. Am $\mathcal{G}$ Med 1986;81:49-55.

Oberg K, Norheim I, Lind E, et al. Treatment of malignant carcinoid tumours with human leucocyte interferon. Long-term results. Cancer Treat Rep 1986;70:1297-304.

8 Bengmark S, Fredlund $P$, Hafström L, Vang J. Present experiences with hepatic dearterialization in liver neoplasm. Progress in Surgery 1974;13:141.

9 Allison DJ, Modlin IM, Jenkins WJ. Treatment of carcinoid liver metastases by hepatic artery embolization. Lancet 1977; ii:1323-5.

10 Maton PN, Camilleri M, Griffin G, Allison DJ, Hodgson HJF, Chadwick VS. Role of hepatic artery embolisation in the carcinoid syndrome. Br Med $\mathcal{F} 1983 ; 287: 932-5$.

11 Coupe M, Hemmingway A, Hodgson HJF, Allison DJ. Effect of hepatic artery embolisation on survival in carcinoid syndrome. Gut 1987;28:A1329.

12 Hodgson HJF, Maton PN. Carcinoid and neuroendocrine tumours. Baillieres Clin Gastroenterol 1987;1:35-61.

13 Bradley PB, Engel G, Feniuk W, et al. Proposals for the classification and nomenclature of functional receptors for 5-hydroxytryptamines. Neuropharmacology 1986;25:563-76.

14 Vroom FQ, Brown RE, Dempsey H, Hill SR. Studies on several possible antiserotonin agents in a patient with the functioning carcinoid syndrome. Ann Intem Med 1962;65:941-5.

15 Gustafsen J, Lendorf A, Raskov H, Boesby S. Ketanserin versus placebo in carcinoid syndrome. Scand f Gastroenterol 1986;21:816-8.

16 Coupe MO, Anderson JV, Morris JA, Alstead EM, Bloom SR, Hodgson HJF. The effects of the 5-hydroxytryptamine $\left(\mathrm{SHT}_{3}\right)$ receptor antagonist ICS $205-930$ in the carcinoid syndrome. Alimentary Pharmacology and Therapeutics 1988;2:167-72.

17 Kvols LK, Moertel CG, O'Connell MJ, Schute AJ, Rudin J, Hahn RG. Treatment of the malignan carcinoid syndrome: evaluation of a long-acting somatostatin analogue. $N$ Engl f Med 1986;315:633-6.

\title{
New Zealand proposals to unshackle hospitals
}

\section{Suggestions to make regional health authorities purchasers of services}

In New Zealand a taskforce comprising Mr Alan Gibbs, Dame Dorothy Fraser, and Sir John Scott has taken a hard look at the organisation of the hospital services. The resulting report is hard hitting and radical. ' It carries some echoes of the Griffiths report, ${ }^{2}$ which it quotes approvingly, but takes a further step that is relevant to the current health services review in Britain.

From the mid-1950s to the 1960s New Zealand had an outstanding health service by world standards. In the 1970s the service deteriorated as New Zealand's economic position declined. Like the British National Health Service, New Zealand's hospital system is essentially publicly owned, administered, and financed. Successive governments held expenditure down, while the calls on the hospitals increased.

The deterioration seems to have been even sharper in New Zealand than in Britain. For example, waiting times increased substantially between December 1978 and December 1987. Not only did the number of people waiting rise by a quarter but also they had on average to wait much longer. The taskforce cites individual examples of over two and a half years for a hip replacement, two years for a cataract operation, two years for a knee replacement, and 18 months for a hernia repair.

The Gibbs taskforce is highly critical of the current performance of New Zealand's hospital system because it does not offer equal access; makes some people wait much too long for treatment; is not sufficiently responsive to changes in public preferences; provides inadequate support to elderly people and others to keep them out of hospital; and is poorly integrated with primary health care. These criticisms are similar to those levelled against the British hospital service.

Arthur Andersen and Company was commissioned to produce a supplementary report on the efficiency of the hospital system. ${ }^{3}$ Using conventional performance measures, the company suggested that large savings could be madebetween $24 \%$ and $32 \%$ of current operating expenses. The methods are open to many criticisms, and the potential savings are certainly exaggerated. Nevertheless, you cannot quarrel with the taskforce's comment that: "There was an appalling absence [in the hospital system] of the kind of data needed to enable the sector to be managed. There was, in fact, little consideration given to the issue of management at all by the health service as a whole."

The resemblance to the Griffiths report is not merely in the bluntness of the language. The taskforce recommends general management in place of the triumvirate-a doctor, a nurse, and an administrator - who currently comprise each hospital's chief executive and operate by consensus. The taskforce remarks: "The troika concept was imported originally from the United Kingdom, where, sensibly, they have now abandoned it." Several other recommendations (such as a rapid improvement in management information) also sound familiar.

What is new, however, and relevant to the British health service review is a proposal to separate financing and provision. "The Ministry of Health would deal solely with policy advice to the minister. The rest of the system would be funded from central government through a newly established National Health Commission to six regional health authorities on a population basis. The six regional health authorities would purchase publicly funded health services from hospitals and other health providers on behalf of the people in their regions. They would not manage or own any services but would contract with public, private and voluntary providers on a competitively neutral basis."

To put the area health boards on an equal starting base (with each other and with private companies) their assets would be valued, target rates of financial return would be prescribed, and financial reporting requirements would be laid down. They would also have freedom to raise loans but without government guarantee. In due course some form of independent ownership for them would be worked out.

The National Health Commission will set up one or more independent professional review organisations to monitor and 
report publicly on the quality and appropriateness of care provided under the new system.

Obviously the details are complicated. The important notion to grasp, however, is that the regional health authorities would not be hierarchically in control of the area health boards. They would be prohibited from owning any institutions or providing any services themselves. Instead, they would act as representatives of their community, purchasing services wherever they could obtain best value-whether from one area health board or another or from the private sector. Some method of payment by case, such as by diagnosis related group, would be used by the regional health authorities to reimburse the providers.

Predictably perhaps, the reaction from the Hospital Boards' Association is against so bold a notion. ${ }^{4}$ Though accepting many of the taskforce's criticisms of the current services, it does not want regional health authorities and thinks that the organisational separation of funding and provision is unnecessary. It remains to be seen what the New Zealand government will decide. Meanwhile, in Britain it is well worth thinking hard about whether our regional health authorities should strip themselves of their current provision functions and instead concentrate on being purchasers and obtaining value for money.

ROBERT J MAXWELL

Secretary and Chief Executive Officer,

King Edward's Hospital Fund for London,

London W2 4HT

1 Hospital and Related Services Taskforce. Unshackling the hospitals. Wellington: New Zealand Government, 1988.

NHS Management Inquiry. Report. London: Department of Health and Social Security, 1983. (Griffiths report.)

3 Arthur Andersen and Co. Public hospital performance assessment. Wellington: New Zealand Department of Health, 1987.

Hospital Board Association of New Zealand. Response to Hospital and Related Services Taskforce report. Wellington: Hospital Boards Association of New Zealand, 1988.

\section{Local anaesthetic creams}

\section{Preparations effective on skin should increase use}

Local anaesthetic creams are generally ineffective when applied to intact human skin because they are poorly absorbed. ${ }^{1}$ This has limited their use to topical anaesthesia of mucous membranes. To diffuse through nerve membranes the local anaesthetic must be in the form of the unchanged base, but formulations in which the lipid soluble free base dissolves easily achieve poor penetration of unbroken skin. This problem seems now to have been overcome with a eutectic ("melting readily") combination of lignocaine and prilocaine. ${ }^{2}$ When mixed together at room temperature crystals of these drugs form an oily liquid. No additional solvent is necessary, so droplets of an oil in water emulsion of lignocaine and prilocaine each have a concentration of $80 \%$ of active drug compared with the $20 \%$ of conventional formulations. The total concentration of local anaesthetic remains low at $5 \%$. The cream is applied under an occlusive plastic dressing.

Lignocaine-prilocaine cream produces effective topical dermal anaesthesia in both children and adults. In placebo controlled studies it reduced significantly the pain of venepuncture or venous cannulation..$^{3-7} \mathrm{~A}$ disadvantage is that the cream must usually be applied for 60 minutes to be effective ${ }^{8}$ though in children aged 1-5 years 30 minutes seems to be sufficient. ${ }^{9}$ Topical anaesthesia persists for at least one hour after removing the cream.

The advantages of avoiding painful needle punctures, particularly in children, are self evident. Not only is subjective discomfort reduced but also the procedure is easier to carry out. Routines in wards and operating rooms may usually be easily arranged to accommodate the minimum application time.

Few local adverse reactions have been reported, although blanching of the skin $^{10}$ (which may persist after removing the cream), erythema, and mild local oedema may occur. Irritation and itching have not been a problem, ${ }^{11}{ }^{12}$ and no delayed hypersensitivity or other allergic reactions have been recorded.

Systemic absorption of lignocaine and prilocaine from this formulation seems to be minimal when applied to intact skin, " but there are no data concerning use on mucous membranes. Topical anaesthesia of mucous membranes may be achieved with lignocaine-prilocaine cream after a few minutes, but the formulation is not recommended for such use until more information is available. There has been one report of methaemoglobinaemia in a 12 week old infant who had had extensive treatment with the cream on the skin over several hours and had also been receiving trimethoprim and sulphamethoxazole for over two months. ${ }^{13}$ Prilocaine and sulphonamides are known to cause the formation of methaemoglobin and may in this case have had an additive effect. Using the cream in older infants is not associated with important increases in methaemoglobin concentration. ${ }^{14}$

Lignocaine-prilocaine cream has been successfully used before lumbar puncture in both adults ${ }^{15}$ and children, ${ }^{16}$ for various dermatological procedures, ${ }^{12}$ and before split skin grafting. ${ }^{17}$ Normally for these procedures infiltration with local anaesthetic would be used but this is painful and may obliterate anatomical landmarks, making the procedure more difficult.

The availability of an effective transdermal preparation of local anaesthetic means that other less obvious indications may be explored. The exquisite hyperaesthesia that may occur with postherpetic neuralgia is extremely difficult to treat but may respond, albeit temporarily, to infiltration with a local anaesthetic and corticosteroid. Trials of lignocaineprilocaine cream are currently under way for this condition, and initial experience indicates that some patients may obtain considerable benefit (C Glynn, unpublished data).

G W HANKS Consultant Physician ISABEL WHITE Research Sister

Royal Marsden Hospital, London SW3 6JJ

1 Adriani J, Dalili H. Penetration of local anesthetics through epithelial barriers. Anesth Analg 1971;50:834-41.

2 Brodin A, Nyqvist-Mayer A, Wadsten I, Forslund B, Broberg F. Phase diagram and aqueous solubility of the lidocaine-prilocaine binary system. I Pharm Sci 1984;73:481-4.

3 Hallen B, Uppfeldt A. Does lidocaine-prilocaine cream permit painfree insertion of IV catheters in children? Anesthesiology 1982;57:340-2

4 Ehrenstrom Reiz GME, Reiz SLA. EMLA-a eutectic mixture of local anaesthetics for topical anaesthesia. Acta Anaesthesiol Scand 1982;26:596-8.

5 Wahlstedt C, Kollberg H, Moller C, Uppfeldt A. Lignocaine-prilocaine cream reduces venepuncture pain. Lancet 1984;ii: 106.

6 Hallen, B, Carlsson P, Uppfeldt A. Clinical study of a lignocaine-prilocaine cream to relieve the pain of venepuncture. Br $\mathcal{Y}$ Anaesth 1985;57:326-8.

7 Manner T, Kanto J, Iisalo E, Lindberg R, Viinamaki O, Scheinin M. Reduction of pain at venous 